\title{
Infeksi biofilm bakterial
}

\author{
Heriyannis Homenta
}

\author{
Bagian Mikrobiologi Fakultas Kedokteran Universitas Sam Ratulangi Manado \\ Email: herihomenta@yahoo.co.id
}

\begin{abstract}
Biofilm is the unity of microbial cell surface surrounded by a matrix of extracellular polymeric substances (EPS). Bacteria composing the biofilm are heterogeneous in space and time. This biofilm continues to grow influenced by internal and external processes. Moreover, biofilm can be found on the surface of medical devices, as well as in bacterial endocarditis and cystic fibrosis. Biofilm that is already formed can lead to antibiotic resistance.
\end{abstract}

Keywords: infections, bacterial biofilm, antibiotic resistance

\begin{abstract}
Abstrak: Biofilm merupakan kesatuan dari permukaan sel mikroba yang dilingkupi oleh matriks substansi polimerik ekstraseluler. Bakteri yag menyusun biofilm bersifat heterogen dalam ruang dan waktu. Biofilm terus berkembang yang dipengaruhi oleh proses internal dan eksternal. Biofilm dapat ditemukan pada permukaan alat-alat medis, endokarditis bakterial, dan kistik fibrosis. Biofilm yang telah terbentuk dapat menyebabkan resistensi antibiotik.
\end{abstract}

Kata kunci: infeksi, biofilm bakterial, resistensi antibiotik

Sejak adanya penemuan mikroskop, maka untuk pertama kali Van Leeuwenhoek mengamati mikroorganisme menggunakan mikroskop pada permukaan gigi dan menemukan biofilm mikroba. Penelitian biofilm yang lebih rinci menggunakan mikroskop elektron dilakukan oleh Jones et al. untuk menilai biofilm pada filter air dalam pengolahan air limbah tanaman dan menunjukkan biofilm terdiri dari berbagai organisme berdasarkan morfologi sel. Dengan menggunakan polisakarida tertentu yang disebut Rutenium merah dan dikopling dengan osmium tetroksida fiksatif, peneliti ini juga mampu menunjukkan bahwa bahan matriks sekitarnya dan yang menutupi sel pada beberapa biofilm ialah polisakarida. ${ }^{1}$

Pada awal tahun 1973, Characklis meneliti mikroba dalam sistem air industri dan menunjukkan bahwa mikroba tidak hanya aktif, tetapi juga sangat tahan terhadap desinfektan seperti klorin. Melalui pengamatan pada plak gigi, Costerton et al. pada tahun 1978 mengajukan teori biofilm yang menjelaskan mekanisme mikroorganisme melekat pada permukaan material hidup dan tidak hidup serta memanfaatkan nutrisi yang diperoleh dari ekologis tersebut. ${ }^{1}$

Pada dua dekade terakhir, penelitian telah mengandalkan alat-alat seperti scanning electron microscopy (SEM) atau teknik kultur standar mikrobiologis untuk karakterisasi biofilm. Dua pernyataan utama tentang biofilm, yaitu pemanfaatan mikroskop pemindai laser konfokal untuk mengkarakterisasi ultrastruktur biofilm, dan penyelidikan gen yang terlibat dalam adhesi sel dan pembentukan biofilm. ${ }^{1}$

\section{Regulasi gen biofilm}

Semakin terbukti bahwa regulasi dari sejumlah gen terjadi pada adhesi sel yang merupakan interaksi awal dengan substrat tersebut. Davies dan Geesey ${ }^{2}$ mendemonstrasikan up-regulation gen algC pada sel bakteri dalam beberapa menit perlekatan 
pada permukaan sel, di mana fenomena ini tidak hanya terbatas pada bakteri $P$. aeruginosa. $^{2}$ Penelitian yang dilakukan oleh Prigent-Combaret et al. ${ }^{3}$ menemukan gen mengalami up-regulation sebesar $22 \%$, dan yang mengalami down-regulation sebesar $16 \%$ pada biofilm, sehingga Prigent-Combaret et al. berpendapat bahwa ekspresi gen biofilm yang terjadi karena dimodulasi oleh faktor eksternal fisikokemikal dinamik pada sel dan merupakan jalur regulator kompleks.

Becker et al. ${ }^{4}$ menunjukkan bahwa biofilm Staphylococcus aureus mengalami up-regulation untuk gen yang mengkode enzim yang berperan pada glikolisis atau fermentasi, yaitu phosphoglycerate mutase, triosephosphate isomerase, dan alcohol dehydrogenase, serta diduga bahwa upregulation dari beberapa gen dapat disebabkan oleh pembatasan oksigen dalam perkembangan biofilm. Penelitian yang dilakukan oleh Pulcini ${ }^{5}$ juga menunjukkan bahwa gen $\operatorname{alg} D, \operatorname{alg} U$, rpoS, dan gen yang mengontrol sintesis polyphosphokinase (PPK) mengalami up-regulation pada formasi biofilm bakteri $P$. aeruginosa.

\section{Struktur biofilm}

Biofilm terdiri dari sel-sel mikroba dan extracellular polymeric substance (EPS). EPS dapat mencakup 50\% sampai 90\% dari total karbon organik biofilm dan dapat dianggap bahan matriks primer biofilm. EPS dapat berbeda sifat kimia dan fisik, tetapi terutama terdiri dari polisakarida. Beberapa polisakarida bersifat netral atau polianionik, seperti EPS bakteri Gram negatif. Adanya asam uronik, seperti $D$ glucuronate, D-galacturonic, dan asam manuronat atau piruvat terkait kental menjadi bahan anionik yang menyebabkan asosiasi kation divalen seperti kalsium dan magnesium, yang telah terbukti bereaksi silang dengan benang polimer dan memberikan kekuatan mengikat yang lebih besar dalam pembentukan biofilm. Pada beberapa bakteri Gram positif, seperti Staphylococci, komposisi kimia dari EPS mungkin sangat berbeda dan terutama bersifat kation. ${ }^{6,7}$ Penelitian Hussain et al. ${ }^{8}$ menemukan bahwa lendir bakteri koagulase-negatif terdiri dari asam teikoik dicampur dengan jumlah kecil dari protein. EPS juga sangat terhidrasi karena dapat menggabungkan sejumlah besar air ke dalam struktur dengan ikatan hidrogen. ${ }^{8}$

EPS dapat bersifat hidrofobik, meskipun sebagian besar EPS bersifat hidrofilik dan hidrofobik, serta bervariasi dalam kelarutannya. Sutherland ${ }^{7}$ mencatat dua sifat penting EPS yang mungkin berefek yang ditandai pada biofilm. Pertama, komposisi dan struktur polisakarida menentukan konfirmasi utama EPS, yaitu banyak EPS bakteri memiliki struktur 1,3- atau 1,4- $\beta$-residu heksosa dan cenderung lebih kaku, kurang dapat berubah bentuk, bahkan dalam kasus-kasus tertentu bersifat sukar larut atau tidak larut, tetapi molekul EPS lainnya mungkin mudah larut dalam air. Kedua, EPS dari biofilm umumnya tidak seragam tetapi dapat bervariasi secara spasial dan sementara. Leriche et al. ${ }^{9}$ menggunakan pengikatan khusus lektin pada gula sederhana untuk mengevaluasi perkembangan biofilm bakteri oleh organisme yang berbeda, dengan hasil penelitian menunjukkan bahwa organisme yang berbeda menghasilkan jumlah EPS yang berbeda dan jumlah EPS meningkat sesuai usia biofilm. ${ }^{9}$ EPS berkaitan dengan ion logam, kation divalen, makromolekul lainnya, seperti protein, DNA, lipid, dan bahkan zat humik. Produksi EPS dipengaruhi oleh nutrisi medium pertumbuhan, kelebihan karbon dan pembatasan nitrogen, kalium, atau fosfat mendukung sintesis EPS. Pertumbuhan bakteri yang lambat akan meningkatkan produksi EPS, karena EPS sangat terhidrasi untuk mencegah kekeringan di beberapa biofilm alami. EPS juga dapat berkontribusi terhadap sifat resistensi antimikroba dari biofilm dengan menghambat transportasi massal antibiotik melalui biofilm. ${ }^{10}$

Tolker-Nielsen dan Molin ${ }^{11}$ menjelaskan bahwa setiap komunitas biofilm mikroba bersifat unik, meskipun beberapa struktur memiliki sifat umum. Istilah 
biofilm dalam beberapa hal keliru, karena biofilm yang tidak mendeposit permukaan monolayer secara kontinu. Sebaliknya, biofilm sangat heterogen, terdiri dari mikrokoloni sel bakteri terbungkus dalam matriks EPS dan dipisahkan dari mikrokoloni lainnya oleh rongga interstitial (saluran air). ${ }^{11,12}$

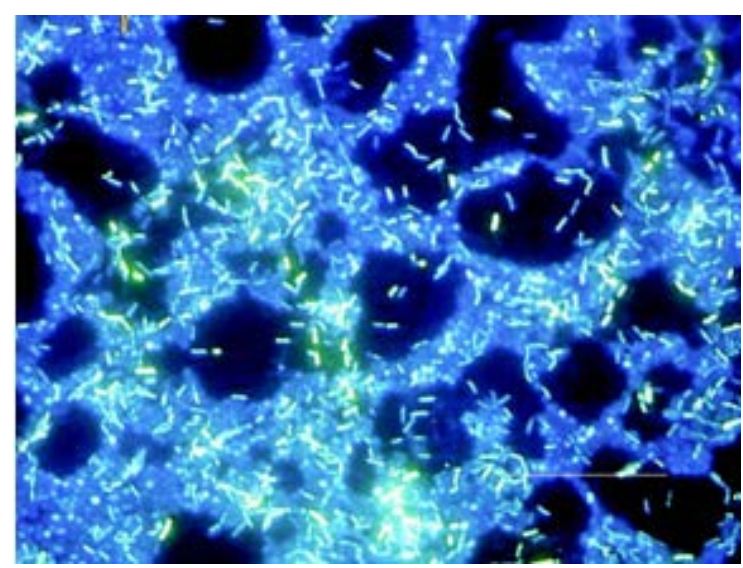

Gambar 1. Biofilm polimikrobial tumbuh pada permukaan stainless steel di laboratorium reaktor biofilm air minum selama 14 hari, kemudian diwarnai dengan 4,6-diamidino-2phenylindole (DAPI) dan diperiksa dengan mikroskop epifluoresens. Sumber: Donlan RM, 2002. ${ }^{1}$

Gambar 1 menunjukkan biofilm $P$. aeruginosa, Klebsiella pneumoniae, dan Flavobacterium spp. yang telah dikembangkan pada permukaan baja di laboratorium sistem air minum yang menjelaskan saluran air dengan karakteristik heterogenitas biofilm yang matang. Aliran cairan terjadi pada saluran air ini, memungkinkan difusi nutrisi, oksigen, dan bahkan agen antimikroba. Konsep heterogenitas menjelaskan tidak hanya untuk campuran kultur biofilm (lingkungan biofilm) tetapi juga untuk kultur murni biofilm umum pada peralatan medis dan yang berhubungan dengan penyakit menular.

Stoodley et al. $^{13}$ mendefinisikan kriteria atau karakteristik tertentu yang bisa dipertimbangkan untuk menjelaskan biofilm umumnya, termasuk film dasar yang tipis, mulai dari pelekatan lapisan tunggal sel menjadi beberapa lapisan film yang tebal yang mengandung saluran air. Penelitian James et al. $^{14}$ menunjukkan penebalan biofilm dapat disebabkan jumlah komponen bakteri. Kultur murni biofilm $K$. pneumoniae atau $P$. aeruginosa di laboratorium reaktor menghasilkan pembentukan biofilm lebih tipis dengan ukuran masing-masing $15 \mu \mathrm{m}$ dan $30 \mu \mathrm{m}$, di mana biofilm yang mengandung kedua spesies bakteri terbentuk lebih tebal dengan ketebalan $40 \mu \mathrm{m} .{ }^{14} \mathrm{Hal}$ ini disebabkan oleh bakteri spesies yang satu meningkatkan kestabilan spesies bakteri yang lain pada pembentukan biofilm.

Struktur biofilm bersifat heterogen baik dalam ruang dan waktu, dan terus berubah karena proses eksternal dan internal. Tolker-Nielsen et al. $^{15}$ meneliti peran motilitas sel pada struktur biofilm dalam aliran sel dengan memeriksa interaksi $P$. aeruginosa dan $P$. putida dengan mikroskop laser konfokal. Kedua bakteri ini ditambahkan dengan sistem aliran sel, maka setiap bakteri akan membentuk mikrokoloni. Seiring dengan waktu, koloni akan bercampur yang menunjukkan migrasi sel dari satu mikrokoloni ke yang lain. Perubahan struktur mikrokoloni dari struktur yang kompak menjadi struktur yang longgar, hal ini dapat terjadi karena sel-sel dalam mikrokoloni menjadi motil, di mana sel yang menyebar berasal dari mikrokoloni biofilm.

Struktur biofilm juga dapat dipengaruhi oleh interaksi komponen partikel nonmikroba, yaitu hospes atau lingkungan, misalnya eritrosit dan fibrin yang terakumulasi pada biofilm. Biofilm pada katup jantung memberikan contoh yang jelas dari jenis interaksi, di mana bakteri mikrokoloni bakterial biofilm berkembang pada matriks trombosit, fibrin, dan EPS. Kapsul fibrin akan melindungi bakteri dalam biofilm dari fagosit leukosit, sehingga menyebabkan infeksi endokarditis. Biofilm pada kateter urine disebabkan oleh bakteri yang memiliki kemampuan untuk menghidrolisis urea dalam urin membentuk amonia bebas 
melalui enzim urease. Amonia dapat meningkatkan $\mathrm{pH}$ di permukaan cairan biofilm, sehingga terjadi pengendapan mineral seperti kalsium fosfat (hidroksiapatit) dan magnesium amonium fosfat (struvite). Mineral yang mengendap dalam biofilm akan menyebabkan kerak pada kateter, seperti kalsium karbonat, produk korosi seperti besi oksida, dan partikel tanah sering terdeposit dalam biofilm yang berasal dari sistem air minum rumahan dan industri, sebagai contoh lain interaksi partikel dengan biofilm. ${ }^{1}$

\section{Infeksi biofilm}

Perbedaan fitur biofilm dengan koloni infeksi ialah adanya agregat mikrokoloni sel yang melekat pada permukaan. Pembentukan biofilm sebagai mekanisme pertahanan memiliki implikasi besar pada hospes karena mikroorganisme yang tumbuh di agregat tertutup matriks ini lebih resisten terhadap antibiotik dan pertahanan hospes. ${ }^{16}$

Parsek dan Singh $^{17}$ mengusulkan empat kriteria untuk mendefinisikan etiologi infeksi biofilm, yaitu bakteri patogen pada permukaan terkait atau melekat pada substrat; pemeriksaan langsung menunjukkan bakteri dalam kluster, terbungkus dalam matriks bakteri atau hospes; infeksi yang terlokalisasi; dan infeksi yang resisten terhadap terapi antibiotik.

Infeksi terkait dengan alat medis merupakan infeksi klinis pertama yang disebabkan oleh biofilm dan menunjukkan bahwa pembentukan biofilm dapat difasilitasi oleh respon inflamasi hospes melalui adhesi ke permukaan alat medis. Alat-alat medis, seperti kateter intravena, katup jantung prostetik, sendi prostetik, kateter dialisis peritoneal, alat pacu jantung, selang cairan serebrospinal dan endotracheal tubes telah menyelamatkan jutaan nyawa, tetapi semua memiliki risiko infeksi intrinsik terkait permukaan. Biofilm terkait dengan alat medis pertama kali dicatat pada awal tahun 1980, melalui mikroskop elektron menunjukkan bakteri yang mengendap pada permukaan perangkat medis, seperti kateter intravena dan alat pacu jantung. ${ }^{16}$

Mikroorganisme yang paling sering dikaitkan dengan alat medis yaitu $S$. epidermidis dan $S$. aureus, diikuti oleh $P$. aeruginosa serta sejumlah bakteri lingkungan yang menyebabkan infeksi oportunis pada hospes yang menggunakan alat intervensi medis invasif, kemoterapi atau keadaan penyakit yang sudah ada. Pembentukan biofilm pada implan medis telah menyebabkan karakterisasi baru penyakit infeksi yang disebut infeksi terkait polimer kronis. Staphylococcus sp. merupakan flora normal kulit dan sering ditemukan di luka dan implan. Menariknya, $S$. epidermidis tidak dianggap sebagai patogen oportunistik sampai meluasnya penggunaan peralatan medis. Pembentukan biofilm dapat dianggap sebagai faktor virulensi, dan merupakan strategi bakteri yang berkontribusi terhadap kemampuannya untuk menyebabkan infeksi. ${ }^{18,19}$

Karakteristik Staphylococcus sp. membentuk koloni pada implan medis ialah jumlah berlebihan EPS (juga dikenal sebagai glycocalyx atau "lendir") yang membungkus dan melindungi sel-sel dari sistem pertahanan tubuh dan pengobatan antibiotik. Pembentukan biofilm ditandai dengan dua tahap utama pada Staphylococcus sp., yaitu adhesi bakteri ke permukaan padat, diikuti oleh pertumbuhan tergantung akumulasi sel yang menghasilkan beberapa lapisan sel kluster. Pada $S$. epidermidis, pembentukan banyak lapisan sel telah dihubungkan khusus pada mekanisme adhesi sel ke sel yang terkait dengan $\beta$-1,6-polisakarida glikosaminoglikan dan dikenal sebagai polysaccharide intercellular adhesin (PIA). Proteins yang terlibat dalam sintesis matriks polisakarida diatur oleh lokus gen ica pada $S$. epidermidis, yaitu lokus yang dikonservasi pada S. epidermidis, S. aureus dan Staphylococcus sp. terkait filogenetik lainnya. Mutasi di lokus ini akan mengganggu pembentukan biofilm terutama mengganggu agregasi dan akumulasi sel, dan strain bakteri dengan PIA dan ica mungkin bisa gagal untuk 
membentuk biofilm jika terjadi kerusakan pada awal adhesi. S. epidermidis dan $S$. aureus menunjukkan pengaruh multifaktorial pada tahap adhesi dan tergantung pada kedua sifat fisikokimia dari bahan polimer biomedis dan sifat permukaan sel bakteri. Secara khusus, hidrofobisitas dan muatan elektrostatik memengaruhi interaksi antara polimer dan permukaan sel bakteri. $^{20-22}$

Protein permukaan bakteri berkontribusi secara signifikan untuk adhesi, dan beberapa protein utama telah diidentifikasi sebagai protein penting dalam pembentukan biofilm Staphylococcus. Bakteri $S$. epidermidis melekat pada polistiren dimediasi oleh AtlE, yaitu autolisin utama. Mutasi pada AtlE dapat mengganggu proses pembentukan biofilm pada polistiren, tetapi tidak pada permukaan kaca, juga kurang hidrofobik dan membentuk kluster sel besar dibandingkan dengan tipe lain. Protein ini juga memediasi pengikatan pada vitronektin, yaitu komponen matriks ekstraselular hospes. Pada bakteri S. aureus, terjadi mutan D-alanine in teichoic acid (dltA) yang menyebabkan perubahan muatan permukaan yang dikompromi dengan kemampuan bakteri untuk melekat pada polistiren atau kaca, meskipun produksi PIA secara utuh. Defek tahap adhesi pada pembentukan biofilm dibentuk kembali dengan penambahan $\mathrm{Mg}^{2+}$. Selain itu, pembentukan biofilm $S$. epidermidis dipengaruhi oleh $\mathrm{Mg}^{2+}$ dan dihambat oleh EDTA; hal ini menjelaskan peran faktor lingkungan pada pengembangan biofilm. Protein permukaan lainnya, termasuk biofilm-associated protein (Bap) dan accumulation-associated protein (AAP), yang penting pada pembentukan biofilm. Mutasi pada Bap memengaruhi pembentukan biofilm dan patogenesis modul infeksi benda asing pada tikus. ${ }^{16,23}$

Hospes juga dapat memberikan kontribusi yang signifikan untuk adhesi pada infeksi terkait alat, terutama dengan Staphylococcus sp. Reseptor spesifik multipel pada sel permukaan disebut adhesin, untuk mengikat molekul hospes (misalnya, protein atau glikoprotein dalam plasma atau platelet atau komponen ekstraseluler hospes). Banyak protein ini merupakan famili microbial surface components that recognize adhesive matrix molecules (MSCRAMMs), yang memediasi adhesi pada berbagai jenis sel hospes serta polimer permukaan dilapisi dengan protein plasma hospes. Beberapa bakteri memiliki adhesin pada fibronektin, merupakan protein hospes yang sering dikaitkan dengan pelekatan bakteri pada permukaan, diikuti oleh fibrinogen atau fibrin, kolagen, laminin dan vitronektin. Fibronektin juga berpartisipasi pada adhesi dengan menjembatani asosiasi dengan fibrin, kolagen, heparin dan glikosaminoglikan permukaan sel hospes lainnya. Dua adhesins fibronektin telah diidentifikasi pada bakteri $S$. aureus, yaitu FnBPA dan FnBPB. ${ }^{24-25}$

Protein mengikat kolagen (Cna) dan dua protein mengikat fibrinogen yang dikenal sebagai faktor penggumpal A dan B (ClfA dan ClfB) juga termasuk famili MSCRAMMs. ClfA juga telah terbukti penting dalam adhesi bakteri $S$. aureus baik pada permukaan polietilen dan polivinil. Jadi, bakteri tertentu memiliki kemampuan untuk memanfaatkan protein hospes yang dihasilkan pada penyembuhan luka atau inflamasi, yang menunjukkan yang adhesin bakteri memiliki mekanisme yaitu kolonisasi pada hospes, tapi jaringan rusak dan perangkat dalam kondisi di mana adanya molekul inflamasi ditandai sebagai infeksi seperti biofilm. ${ }^{26}$

Endokarditis bakterial menunjukkan mekanisme mikroorganisme pada kulit atau dalam rongga mulut yang masuk ke pembuluh darah dan menyebabkan koloni abnormal di katup atau endotelial jantung. Terjadi pelekatan dalam vegetasi akibat interaksi antara sel mikroba dan produk hospes. Bakteri Streptococcus sp. Merupakan etiologi pada lebih dari setengah kasus endokarditis, dan bersama dengan Staphylococcus sp. pada seperempat kasus endokarditis. Banyak strain bersifat komensal di kulit dan rongga mulut. Secara klinis, lesi endokarditis bakterial disebut 
vegetasi, terdiri dari agregat sel bakteri, trombosit dan fibrin yang melekat pada epitel rusak dari katup jantung. Endokarditis dikaitkan dengan cacat jantung bawaan, katup jantung prostetik dan cangkokan pembuluh darah, dan disebabkan oleh gumpalan dari platelet dan fibrin, di mana terjadi penimbunan aliran turbulen yang diperburuk oleh jaringan abnormal, penyakit jantung yang sudah ada atau kateter vaskular. Kerusakan endotelium yang mendasari membran basal, yang terdiri dari kolagen, laminin, vitronektin dan fibronektin, sehingga memberikan substratum untuk adhesi bakteri (tahap awal dalam patogenesis endokarditis). Selain itu, setelah kerusakan endotel dan terjadi turbulensi aliran darah, proses inflamasi merangsang sistem pembekuan, yang menyebabkan pengendapan fibrin dan bekuan tidak larut fibrin dan platelet. ${ }^{16,27}$

Penelitian yang dilakukan oleh Durack menunjukkan bahwa adhesi bakteri Streptococcus sanguis ke permukaan vegetasi steril dan mulai bereplikasi dalam waktu 30 menit setelah injeksi ke dalam kateter kelinci. Mikrokoloni Streptococcus sp. berkembang di dalam trombus dan dikelilingi oleh fibrin yang menghambat interaksi leukosit. Setelah empat minggu pasca infeksi, vegetasi diperiksa maka tampak bakteri Streptococcus sp. di dalam lesi kalsifikasi yang dikelilingi oleh fibroblas. Aktivitas metabolik bakteri dalam vegetasi tampak berkurang dibandingkan dengan bakteri di perifer, tetapi konsisten dengan pembentukan biofilm dalam vegetasi. Selanjutnya, vegetasi tumbuh dengan penambahan lapisan fibrin dan trombosit, dengan koloni bakteri berada di antara fibrin dan trombosit, yang mengindikasikan siklus trombosis dan kolonisasi bakteri lebih lanjut. $^{16}$

Penelitian Höök dan Sand pada kelinci menunjukkan bahwa kolonisasi bakteri terjadi meskipun vegetasi dicegah dengan pengobatan antikoagulan, yang menunjukkan bahwa adanya gumpalan, tetapi tidak perlu untuk endokarditis. Menariknya, perjalanan penyakit itu sangat berbeda, di mana pada kelinci yang diobati dengan antikoagulan, penyakit ini lebih fulminan dan hewan menunjukkan bakteremia lebih tinggi serta tingkat kelangsungan hidup lebih rendah. Berbeda dengan hewan tanpa pengobatan antikoagulan yang menunjukkan infeksi subakut, atau kronis yang lebih resisten terhadap terapi antibiotik. Vegetasi terdiri dari koloni bakteri yang besar, padat dengan fibrin dan platelet serta dikelilingi oleh fibrin. Peneliti berpendapat bahwa bakteri dalam vegetasi dengan metabolik yang kurang aktif dan struktur vegetasi serupa yang diamati pada manusia. Ramirez-Rhonda meneliti Streptococcus $s p$. karena kemampuan bakteri tersebut untuk melekat pada katup jantung dan menemukan bahwa strain yang menghasilkan EPS terdiri dari glukan dan dekstran yang melekat baik untuk katup jantung yang rusak. ${ }^{16}$

Penelitian terbaru yaitu Streptococcus parasanguis membentuk koloni pada permukaan gigi manusia dan oportunis yang ditemukan pada endokarditis katup jantung asli dan palsu, gen pengkode fimbriae peritrichous, yaitu fap1, terbukti berhubungan dengan pembentukan biofilm pada plastik, dan fap1 mutan menunjukkan adhesi yang terbatas, tetapi terutama gagal pada agregat dan pembentukan mikrokoloni. Penelitian Fey et al. menunjukkan korelasi antara hemaglutinasi dan pembentukan biofilm pada S. epidermidis, di mana ada hubungan antara PIA, adhesi intersel dan adhesi pada eritrosit. Defek strain PIA yang ditemukan pada bakteri kurang virulen dari model endokarditis kelinci. Demikian pula, bakteri S. aureus mutan yang menyebabkan defek adhesi pada platelet, berkorelasi dengan penurunan virulensi pada model endokarditis kelinci, yang ditandai dengan lebih sedikit bakteri dalam vegetasi dan penurunan embolisasi. $^{16,28}$

Bakteri S. aureus mutan menyebabkan defek pada fibronektin mengikat dan penurunan mengikat katup jantung yang rusak. Faktor penggumpalan ClfA, protein mengikat fibrinogen pada $S$. aureus yang 
memediasi adhesi $S$. aureus pada plastik, tampaknya memiliki peran spesifik pada model endokarditis tikus. Penelitian mutan dan komplementasi menunjukkan bahwa clfA penting pada adhesi pada permukaan dan virulensi, walaupun endokarditis masih terjadi dengan inokulum besar dari dari clfA mutan. Namun, ClfA dan FnbA (adhesin lain) yang ko-ekspresi pada bakteri non-virulen, yaitu Lactococcus lactis menyebabkan endokarditis pada model tikus sebanding dengan spesies patogen. Adhesin ClfA untuk mengikat bakteri $S$. aureus pada platelet manusia secara langsung yang sebelumnya tidak dikarakteristik reseptor membran platelet. $^{29,30}$

Terapi antibiotik dalam pengobatan endokarditis juga konsisten dengan peran biofilm. Penelitian secara in vivo pada model kelinci dengan bakteri E. coli sebagai agen infeksi diperlukan konsentrasi antibiotik berkelanjutan dengan 220 kali konsentrasi bakterisida minimum serum. Bahkan pada saat vegetasi diterapi secara ex vivo, efek antibakteri dalam vegetasi diperlukan 150 kali konsentrasi bakterisida minimal. ${ }^{16}$

Cystic fibrosis (CF) adalah penyakit autosomal resesif yang disebabkan oleh mutasi pada gen cystic fibrosis conductance regulator (CFTR) yang menyebabkan disfungsional sekresi dan absorpsi elektrolit. Adanya patofisiologi yang kompleks dengan lokasi utama morbiditas ialah sistem pernapasan. Penurunan hidrasi pada cairan permukaan jalan nafas menyebabkan lendir pernapasan lebih kental dan mengganggu pembersihan mukosiliar, infeksi bakteri endobronkial kronis, dan inflamasi jalan napas, yang mengarah ke obstruksi jalan napas, dekstruksi progresif epitel saluran napas dan pada akhirnya terjadi gagal napas. Kolonisasi bakteri di saluran pernapasan bagian bawah pada pasien CF dimulai sejak bayi atau anak usia dini, paling sering disebabkan bakteri $S$. aureus dan Haemophilus influenzae namun, pada saat remaja dan dewasa disebabkan oleh $P$. aeruginosa. Pergeseran kolonisasi menjadi infeksi kronis dengan $P$. aeruginosa merupakan hasil lingkungan khas dari CF pneumonia, yang meliputi reseptor pada epitel sel yang memfasilitasi adhesi Pseudomonas sp. yang memperberat gangguan pembersihan mukosiliar. ${ }^{16,31}$

Terdapat dua ciri utama tentang kolonisasi CF paru dengan $P$. aeruginosa. Pertama, $P$. aeruginosa tumbuh dalam biofilm berada dalam CF paru. Analisis mikroskopis sputum pasien CF menunjukkan bahwa $P$. aeruginosa membentuk struktur seperti biofilm yang terdiri dari kelompok bakteri dikelilingi oleh matriks padat. Morfologi struktur yang serupa telah diobservasi pada spesimen CF paru. Selanjutnya, homoserine lactone (HSL), signal quorum sensing (QS) diukur pada sputum CF yang konsisten dengan profil $P$. aeruginosa yang tumbuh dalam biofilm. ${ }^{32}$

Ciri yang kedua kolonisasi $P$. aeruginosa pada CF paru merupakan seleksi varian mukoid $P$. aeruginosa, di mana ditandai oleh produksi yang berlebihan eksopolisakarida alginat, dan resistensi terhadap antibiotik. Awalnya, $P$. aeruginosa diisolasi dari paru pasien CF yang non-mukoid. Namun, isolat berlendir biasanya berkaitan dengan infeksi kronis persisten. Menariknya, tidak ada varian berlendir di antara isolat lingkungan $P$. aeruginosa, meskipun strain non-mukoid tampaknya memiliki genotipe untuk berlendir. Penelitian menunjukkan bahwa respon inflamasi hospes berkontribusi pada konversi berlendir. Mathee et al. ${ }^{33}$ menumbuhkan $P$. aeruginosa dalam biofilm dan memaparkan biofilm ini dengan hidrogen peroksida (H2O2) eksogen atau polymorphoneutrophil (PMN) manusia yang diaktifkan secara in vitro. Penelitian menunjukkan bahwa konversi mukoid konsisten dengan delesi kerangka baca terbuka mucA, dan delesi yang sama juga diamati pada $25 \%$ isolat mukoid dari pasien CF. Oleh karena itu, P. aeruginosa merespon lingkungan mikro CF paru dengan memodifikasi fenotip.

Mekanisme spesifik kolonisasi $P$. aeruginosa pada CF paru tidak diketahui. Suatu hipotesis menyatakan bahwa 
inflamasi saluran napas menyebabkan pelekatan $P$. aeruginosa pada epitel saluran napas. Penelitian menemukan bahwa sekresi bronkial CF memiliki aktivitas proteolitik melawan fibronektin yang berhubungan dengan mukosa pernafasan, yang mendukung kolonisasi $P$. aeruginosa lebih dari kolonisasi S. aureus. Penelitian yang lain menunjukkan bahwa $P$. aeruginosa melekat pada polip hidung, karena modifikasi sel epitel oleh eksoproduk bakteri yang terkena tempat mengikat asialoganglioside yang memfasilitasi pelekatan Pseudomonas. Model ex vivo yang sama, bakteri $P$. aeruginosa ditemukan melekat pada sel epitel undiferensiasi yang mengalami perbaikan, khususnya antara integrin $\alpha v \beta 1$ dan reseptor fibronektin RGD (Arg-Gly-Asp) pada sel epitel dan protein membran luar (OMP) $P$. aeruginosa. $P$. aeruginosa memiliki beberapa adhesins dan mengikat berbagai reseptor dan jenis sel di saluran pernafasan. ${ }^{16,34,35}$

Molekul QS 3-oxo-C12-HSL yang dihasilkan oleh $P$. aeruginosa juga memiliki efek modulator pada sel epitel pernapasan. Kultur bronkial sel epitel memproduksi interleukin (IL)-8 merupakan sitokin inflamasi yang merespon terhadap bakteri P. aeruginosa, dan kemudian menunjukkan efek yang disebabkan oleh 3oxo-C12-HSL. Selain itu, 3-oxo-C12-HSL menginduksi ekspresi sitokin inflamasi dan kemokin lainnya, seperti IL-1, IL-6 dan interferon (INF)- $\gamma$, dan beberapa protein inflamasi makrofag, serta menginduksi siklooksigenase 2 (COX-2) dan prostaglandin E2 (PGE2) di fibroblas paru manusia. Hasil ini menunjukkan bahwa bakteri $P$. aeruginosa menginduksi pelepasan mediator inflamasi dan infiltrasi leukosit ke jaringan paru. ${ }^{36,37}$

Hipotesis mekanisme lain dari kolonisasi bakteri di CF berimplikasi pada lapisan mukosa. Pada model ini, peningkatan viskositas mukus saluran napas CF bertindak sebagai perancah matriks dan penting dalam penurunan neutralisasi. Penelitian Worlitzsch et al. ${ }^{38}$ pada pasien CF disertai penyakit paru kronis dengan menggunakan mikroskop elektron dan jaringan eksplan, dan menemukan $P$. aeruginosa pada mukopurulen hipoksia "makrokoloni" dengan diameter $100 \mu \mathrm{m}$ di saluran jalan napas daripada melekat epitel. Penelitian in vivo dan in vitro menggunakan mikroelektroda menunjukkan bahwa oksigen berkurang di makrokoloni mukoid. Selanjutnya, bakteri $P$. aeruginosa menembus lapisan mukosa hipoksia dan merespons kondisi anaerob dengan memproduksi lebih banyak alginat. Hasil ini menyatakan bahwa lingkungan lokal di CF paru, yang ditandai dengan plak mukosa tebal dan penurunan $\mathrm{O} 2$ pada epitel pernapasan menyebabkan kolonisasi oleh $P$. aeruginosa yang memperburuk CF pneumonia. $^{38}$

Penelitian Yoon et al. ${ }^{39}$ juga menunjukkan suasana anaerob menjadi ciri penting dari pertumbuhan $P$. aeruginosa dalam biofilm pada pasien CF. bakteri $P$. aeruginosa membentuk biofilm yang kuat dalam suasana anaerob yang menyebabkan penumpukan metabolit nitrogen toksik. Analisis proteomik mengidentifikasi porin membran luar, OprF, konsentrasi yang meningkat 40 kali lipat pada kultur anaerob. OprF juga terdeteksi dalam sekresi dari CF paru dan antibodi melawan OprF ditemukan pada pasien CF kronis. Penelitian ini menunjukkan mekanisme beberapa aspek klinis CF pneumonia yang disebabkan bakteri $P$. aeruginosa, ketidakefektifan fagosit terhadap $P$. aeruginosa, fenotip mukoid $P$. aeruginosa dan resistensi biofilm $P$. aeruginosa terhadap tobramycin. ${ }^{39-40}$

Menariknya, resistensi antibiotik bakteri $P$. aeruginosa dan pembentukan biofilm tampaknya diinduksi pada waktu yang sama. Pada saat resistensi antibiotik diteliti dalam isolat klinis $P$. aeruginosa, perbedaan fenotipe yang berhubungan dengan kedua kemampuan yang ditingkatkan untuk bentuk biofilm dan meningkatkan resistensi antibiotik, di mana fenotip diamati baik in vitro dan pada pasien CF dengan terapi antibiotik. Varian yang resistensi juga muncul lebih sering 
dalam menanggapi pengaruh lingkungan, seperti perubahan dalam konsentrasi garam. Spekulasi tentang varian fenotipik resisten antibiotik dari $P$. aeruginosa pada infeksi CF yang dipilih dalam biofilm dengan pengobatan antibiotik sub-letal, atau dengan lingkungan spesifik CF paru yang ditandai dengan osmotik dan stres oksidatif. Penelitian ini menunjukkan bahwa keduanya bertanggung jawab untuk fenotip yang resisten. ${ }^{41}$

Pada lingkungan kompleks CF paru, tidak seperti mekanisme eksklusif patologi, dan karena itu respon inflamasi hospes menyebabkan perubahan dalam lingkungan mikro lokal untuk merespon terhadap bakteri $P$. aeruginosa. CF pneumonia merupakan interaksi kompleks antara bakteri dan pengaruh lingkungan lokal hospes yang disebabkan oleh respon inflamasi yang berkontribusi pada patologi kompleks penyakit ini. ${ }^{16}$

\section{SIMPULAN}

Biofilm adalah suatu kesatuan dari selsel mikroba dan extracellular polymeric substance (EPS). Perkembangan biofilm dipengaruhi oleh proses internal dan eksternal, dan biofilm yang telah terbentuk dapat menyebabkan resistensi antibiotik.

\section{DAFTAR PUSTAKA}

1. Donlan RM. Biofilm: Microbial life on surfaces. Emerging Infectious Diseases. 2002;8:881-90.

2. Davies DG, Geesey GG. Regulation of the alginate biosynthesis gene $\operatorname{algC}$ in Pseudomonas aeruginosa during biofilm development in continuous culture. Appl Environ Microbiol. 1995;61:860-7.

3. Prigent-Combaret C, Vidal O, Dorel C, Lejeune $\mathbf{P}$. Abiotic surface sensing and biofilm-dependent regulation of gene expression in Escherichia coli. J Bacteriol. 1999; 181:5993-6002.

4. Becker P, Hufnagle W, Peters G, Herrmann M. Detection of different gene expression in biofilm-forming versus planktonic populations of Staphylococcus aureus using microrepresentational-difference analysis.
Appl Environ Microbiol. 2001;67: 2958-65.

5. Pulcini E. The effects of initial adhesion events on the physiology of Pseudomonas aeruginosa [Ph.D. dissertation]. Bozeman (MT): Montana State University; 2001.

6. Flemming H-C, Wingender JG, Mayer C. Physico-chemical properties of biofilms. In: Evans LV, editor. Biofilms: recent advances in their study and control. Amsterdam: Harwood Academic Publishers, 2000; p. 19-34.

7. Sutherland IW. Biofilm exopolysaccharides: a strong and sticky framework. Microbiology; 2001;147: 3-9.

8. Hussain M, Wilcox MH, White PJ. The slime of coagulase-negative staphylococci: biochemistry and relation to adherence. FEMS Microbiol Rev. 1993;104:191-208.

9. Leriche V, Sibille P, Carpentier B. Use of an enzyme-linked lectinsorbent assay to monitor the shift in polysaccharide composition in bacterial biofilms. Appl Environ Microbiol. 2000;66: 1851-6.

10. Donlan RM. Role of biofilms in antimicrobial resistance. ASAIO J. 2000;46;S47-S52.

11. Tolker-Nielsen $T$, Molin $\quad$ S. Spatial organization of microbial biofilm communities. Microb Ecol. 2000;40: 75-84.

12. Lewandowski Z. Structure and function of biofilms. In: Evans LV, editor. Biofilms: Recent advances in their study and control. Amsterdam: Harwood Academic Publishers, 2000; p. 1-17.

13. Stoodley P, Boyle JD, Dodds I., LappinScott HM. Consensus model of biofilm structure. In: Wimpenny JWT, Gilbert PS, Lappin-Scott HM, Jones $\mathrm{M}$, editors. Biofilms: community interactions and control. Cardiff, UK: Bioline, 1997; p. 1-9.

14. James GA, Beaudette L, Costerton JW. Interspecies bacterial interactions in biofilms. Journal of Industrial Microbiology. 1995;15:257-62.

15. Tolker-Nielsen T, Brinch UC, Ragas PC, Andersen JB, Jacobsen CS, Molin 
S. Development and dynamics of Pseudomonas sp. biofilms. J Bacteriol. 2000;182:6482-9.

16. Hall-Stoodley L, Costerton JW, Stoodley P. Bacterial biofilms: from the natural environment to infectious diseases. Nature review microbiology. 2004;2: 95-108.

17. Parsek MR, Singh PK. Bacterial biofilms: an emerging link to disease pathogenesis. Annu. Rev. Microbiol. 2003;57;677-701.

18. von Eiff $C$, Heilmann C, Hermann $M$, Peters G. Basic aspects of the pathogenesis of Staphylococcal polymerassociated infections. Infection. 1999;27:S7-S10.

19. Akiyama H, Huh WK, Yamasaki O, Oono T, Iwatsuki K. Confocal laser scanning microscopic observation of glycocalyx production by Staphylococcus aureus in mouse skin: does $S$. aureus generally produce a biofilm on damaged skin? Br. J. Dermatol. 2002;147:879-85.

20. Heilmann C, Hussain M, Peters G, Gotz F. Evidence for autolysin-mediated primary attachment of Staphylococcus epidermidis to a polystyrene surface. Mol. Microbiol. 1997;24: 1013-24.

21. Heilmann C, Gerke C, PerdreauRemington F, Gotz F. Characterization of Tn917 insertion mutants of Staphylococcus epidermidis affected in biofilm formation. Infect. Immun. 1996;64:277-82.

22. Heilmann C, Schweitzer O, Gerke C, Vanittanakom N, Mack D, Gotz F. Molecular basis of intercellular adhesion in the biofilm-forming Staphylococcus epidermidis. Mol. Microbiol. 1996;20:1083-91.

23. Gross M, Cramton SE, Gotz F, Peschel A. Key role of teichoic acid net charge in Staphylococcus aureus colonization of artificial surfaces. Infect. Immun. 2001;69:3423-6.

24. Vaudaux PE, Lew DP, Waldvogel F. In: Bisno AL, Waldvogel FA, editors. Infections Associated with Indwelling Medical Devices (2nd ed). Washington DC: ASM Press, 1994.
25. Foster TJ, Höök M. Surface protein adhesins of Staphylococcus aureus. Trends Microbiol. 1998;6:484-8.

26. Vaudaux PE, Francois $P$, Proctor RA, McDevitt D, Foster TJ, Albrecht RM. Use of adhesion defective mutants of Staphylococcus aureus to define the role of specific plasma proteins in promoting adhesion to arteriovenous shunts. Infect. Immun. 1995;63:585-90.

27. Donlan RM, Costerton JW. Biofilms: survival mechanisms of clinically relevant microorganisms. Clin Microbiol Rev. 2002;15:167-93.

28. Fey PD, Ulphani JS, Gotz F, Heilmann C, Mack D, Rupp ME. Characterization of the relationship between polysaccharide intercellular adhesin and hema-gglutination in Staphylococcus epidermidis. J Infect Dis. 1999;179: 1561-4.

29. Que YA, Francois $P$, Haefliger J-A, Entenza J-M, Vaudaux $P$, Moreillon P. Reassessing the role of Staphylococcus aureus clumping factor and fibronectin-binding protein by expression in Lactococcus lactis. Infect. Immun. 2001;69:6296-302.

30. Siboo IR, Cheung AL, Bayer AS, Sullam PM. Clumping factor A mediates binding of Staphylococcus aureus to human platelets. Infect Immun. 2001;69:3120-7.

31. Lyczak JB, Cannon CL, Pier GB. Lung infections associated with cystic fibrosis. Clin Microbiol Rev. 2002; 15:194-222.

32. Singh PK, Schaefer AL, Parsek MR, Moninger TO, Welsh MJ, Greenberg EP. Quorum-sensing signals indicate that cystic fibrosis lungs are infected with bacterial biofilms. Nature. 2000;407:762-4.

33. Mathee K, Ciofu O, Sternberg C, Lindum PW, Campbell JI, Jensen P, et al. Mucoid conversion of Pseudomonas aeruginosa by hydrogen peroxide: a mechanism for virulence activation in the cystic fibrosis lung. Microbiology. 1999; 145:1349-57.

34. Roger P, Puchelle E, Bajolet-Laudinat O, Tournier JM, Debordeaux C, et al. Fibronectin and $\alpha 5 \beta 1$ integrin 
mediate binding of Pseudomonas aeruginosa to repairing airway epithelium. Eur Respir J. 1999;13:1301-9.

35. Ofek I, Hasty DL, Doyle RJ (editors). Bacterial Adhesion to Animal Cells and Tissues. Washington DC: ASM Press, 2003.

36. Smith RS, Harris SG, Phipps R, Iglewski B. The Pseudomonas aeruginosa quorum-sensing molecule $\mathrm{N}-(3-$ oxododecanoyl) homoserine lactone contributes to virulence and induces inflammation in vivo. $\mathrm{J}$ Bacteriol. 2002;184:1132-9.

37. Smith RS, Kelly R, Iglewski BH, Phipps RP. The Pseudomonas autoinducer N-(3-oxododecanoyl) homoserine lactone induces cyclooxygenase- 2 and prostaglandin E2 production in human lung fibroblasts: implications for inflammation. J Immunol. 2002;169: 2636-42.
38. Worlitzsch D, Tarran R, Ulrich $M$, Schwab U, Cekici A, Meyer KC, et al. Effects of reduced mucus oxygen concentration in airway Pseudomonas infections of cystic fibrosis patients. J Clin Invest. 2002;109:317-25.

39. Yoon SS, Hennigan RF, Hilliard GM, Oschner UA, Parvatiyar K, Kamani MC, et al. Pseudomonas aeruginosa anaerobic respiration in biofilms: relationships to cystic fibrosis pathogenesis. Dev Cell. 2002;3:593-603.

40. Xu KD, Stewart PS, Xia F, Huang CT, McFeters GA. Spatial physiological heterogeneity in Pseudomonas aeruginosa biofilm is determined by oxygen availability. Appl Environ Microbiol. 1998;64:4035-9.

41. Drenkard E, Ausubel FM. Pseudomonas biofilm formation and antibiotic resistance are linked to phenotypic variation. Nature. 2002;416:740-3. 